\title{
ANALISIS KINERJA GURU KIMIA SMA DKI JAKARTA DITINJAU DARI KECERDASAN EMOSIONAL
}

\author{
SUMIYATI \\ sumiyatigultom17@gmail.com \\ Universitas Kristen Indonesia
}

\begin{abstract}
This study used an analysis of performance's teacher of chemistry teacher of DKI Jakarta High School seen from Emotional Intelligence. The purpose of this study is to determine whether there is a relationship between the intelligence of teachers and high school teacher teachers in DKI Jakarta. The research method used in this study is a survey method with correlational design. Respondents involved in the study of information were 118 chemistry teachers from State High Schools in DKI Jakarta. The results showed that there was a significant positive relationship between emotional intelligence and the performance of chemistry teachers. There is no higher than the chemistry teacher who is higher than them. It can be concluded that to have a good teacher performance, the teacher must train or improve his emotional intelligence.
\end{abstract}

Keywords: Teacher Performance, Emotional Intelligence

\begin{abstract}
ABSTRAK
Penelitian ini mengenai analisis kinerja guru kimia SMA DKI Jakarta dari Kecerdasan Emosional. Adapun tujuan penelitian ini untuk mengetahui ada tidaknya hubungan antara kecerdasan emosional guru dengan kinerja guru kimia SMA di DKI Jakarta. Adapun metode penelitian yang digunakan pada penelitian ini adalah metode survey dengan desain korelasional. Responden yang terlibat dalam penelitian melibatkan 118 orang guru kimia SMA Negeri di DKI Jakarta. Hasil penelitian menunjukkan bahwa terdapat hubungan positif yang siqnifikan antara kecerdasan emosional dan kinerja guru kimia. Artinya semakin tinggi kecerdasan emosional guru kimia maka semakin tinggi kinerja mereka. Dapat disimpulkan bahwa untuk memiliki kinerja guru yang baik, maka guru harus melatih atau meningkatkan kecerdasan emosionalnya.
\end{abstract}

Kata Kunci: Kinerja Guru, Kecerdasan Emosional 
Sumiyati, Analisis Kinerja Guru Kimia SMA DKI Jakarta Ditinjau dari Kecerdasan Emosional

\section{Pendahuluan}

Secara garis besar, faktor yang sangat berpengaruh terhadap mutu pendidikan di Indonesia dapat diduga dipengaruhi oleh faktor internal siswa, faktor eksternal dan faktor proses transfer ilmu pengetahuan dari guru. Walaupun peran guru tidak terlalu besar, akan tetapi cukup menentukan tinggi atau rendahnya mutu pendidikan di Indonesia. Sehubungan dengan hal ini, ternyata gurupun banyak mendapatkan sorotan dari masyarakat umum. Setiap kali orang berbicara tentang mutu pendidikan yang rendah, maka tidak sedikit kesalahan itu dilimpahkan kepada guru. Walau seluruhnya tidak benar, akan tetapi semestinya guru juga tidak menutup diri akan adanya kemungkinan penyebab itu diakibatkan oleh guru, yaitu kinerja guru yang belum maksimal.

Selanjutnya, walaupun belum banyak penelitian yang mengungkapkan kinerja guru dalam kaitannya dengan tugas utama melaksanakan pembelajaran, dapat diasumsikan bahwa kinerja guru pada umumnya masih rendah. Hal ini dapat dicermati dari hasil Nilai Ebtanas Murni (NEM) siswa dari tahun ke tahun yang belum sesuai dengan yang diharapkan (1998: 51). Data-data Nilai Ebtanas Murni (NEM) untuk wilayah DKI, pada tahun 1997/1998 rata-rata NEM siswa untuk mata pelajaran Kimia adalah 4,93; tahun 1998/1999 adalah 5,32; tahun 1999/2000 adalah 5,84; dan tahun 2000/2001 adalah 5,03. Data tersebut menunjukkan daya serap rata-rata lulusan SMA terhadap materi kimia dari tahun ke tahun masih rendah sehingga belum mencapai target yang diharapkan dalam tujuan-tujuan pendidikan di SMA. Oleh karena itu kinerja guru merupakan salah satu faktor yang mempengaruhi keberhasilan Iulusan, dan mutu pendidikan pada umumnya.

Hasil uji kompetensi guru yang dilakukan oleh Kanwil Diknas DKI Jakarta (Depdiknas 
1999 : 56), yaitu untuk guru kimia rata-rata hanya mencapai nilai 45,63. Sedangkan hasil lomba penguasaan dan pemahaman kurikulum 1994 dan suplemennya di tingkat SMA di DKI Jakarta (Depdiknas 1999 : 8), untuk 411 orang guru, 235 orang mendapat nilai antara 4,01 - 5,55; 66 orang mendapat nilai $5,51-7,00,8$ orang mendapat nilai antara 7,01 - 8,50, dan 1 orang guru memperoleh nilai $8,51-10,00$. Gambaran ini menunjukkan bahwa penguasaan materi kimia maupun materi kurikulum tahun 1994 mata pelajaran kimia masih rendah.

Hasil penelitian Jiyono dan Koster dalam Suprastowo (2001: 10) menunjukkan, tingkat penguasaan materi ajar guru kimia sebesar $63 \%$ dari seluruh materi pelajaran yang semestinya dikuasai. Selain itu, hasil laporan Bahrul Hayat dan Yahya Umar (dalam Adiningsih, $2004: 5$ ) memperlihatkan, nilai rata-rata nasional tes calon guru Pegawai Negeri Sipil (PNS) di Sekolah Lanjutan Tingkat Atas (SLTA) tahun 1998/1999 untuk bidang studi kimia adalah 43,55 dari interval 0-100. Artinya hanya menguasai $43,55 \%$ dari materi yang seharusnya.

Rendahnya kemampuan guru dalam menguasai materi menjadi kendala utama bagi kinerja guru. Agar guru dapat melaksanakan tugasnya dengan baik, guru harus menyadari tanggung jawabnya. Sedangkan kesadaran seorang guru untuk meningkatkan pembelajaran merupakan salah satu ciri kecerdasan emosional. Mungin dalam tulisannya mengatakan bahwa kecerdasan emosional merupakan salah satu indikator kebermutuan guru (1996: 1). Oleh karena itu, kecerdasan emosional diduga merupakan salah satu komponen yang dapat mempengaruhi kinerja guru kimia.

Hal inilah yang menjadi latar belakang penelitian ini, yaitu untuk membutktikan secara komprehensif dan mendalam mengenai hubungan kecerdasan emosional dengan kinerja guru 
Sumiyati, Analisis Kinerja Guru Kimia SMA DKI Jakarta Ditinjau dari Kecerdasan Emosional

kimia SMA Negeri di DKI Jakarta. Hal ini hanya bisa dijawab dengan melakukan kajian melalui penelitian terhadap fenomena tersebut. Adapun tujuan kajian ini dilakukan untuk mengetahui ada atau tidaknya hubungan antara kecerdasan emosional dengan kinerja guru kimia.

\section{Kajian Literatur}

Dalam melakukan suatu
pekerjaan atau dalam
melaksanakan tugas-tugas yang
menjadi tanggung jawab
seseorang, maka yang menjadi
tolok ukur adalah kinerja.
Sehubungan dengan kinerja,
banyak batasan yang diberikan
oleh para ahli mengenai istilah
ini. Secara prinsip para ahli setuju
bahwa kinerja mengarah pada
suatu upaya dalam rangka
mencapai prestasi kerja yang
lebih baik. Dalam Kamus Bahasa
Indonesia (1996: 503), kinerja
diberikan pengertian sebagai: (1)
sesuatu yang dicapai, (2) prestasi
yang diperlihatkan, dan (3)
kemampuan kerja. Maier sebagaimana dikutip oleh As'ad
(1995: 47) mengatakan bahwa kinerja merupakan kesuksesan seseorang di dalam melaksanakan suatu pekerjaan. Hal ini menjelaskan bahwa kinerja adalah hasil yang dicapai seseorang menurut ukuran yang berlaku untuk pekerjaan yang bersangkutan. Kinerja seseorang dapat terlihat melalui aktivitasnya dalam melaksanakan pekerjaan sehari-hari. Aktivitas ini menggambarkan bagaimana ia berusaha untuk mencapai tujuan yang telah ditetapkan. Dengan kata lain, kinerja seseorang terkait dengan bagaimana ia melakukan tugas dan hasil yang telah diraih.

Selanjutnya John
Whitmore (1997: 104)
berpendapat, bahwa kinerja
sebagai suatu perbuatan, suatu
prestasi, suatu pameran umum
keterampilan. Dengan demikian,
kinerja mengandung pengertian
adanya suatu perbuatan yang
ditampilkan seseorang di dalam
atau selama orang tersebut
melakukan aktivitas tertentu.
104) berpendapat, bahwa kinerja sebagai suatu perbuatan, suatu prestasi, suatu pameran umum keterampilan. Dengan demikian, adanya suatu perbuatan yang ditampilkan seseorang di dalam melakukan aktivitas tertentu. 
Berdasarkan pengertianpengertian di atas, maka dapat disimpulkan bahwa kinerja merupakan prestasi yang dicapai seseorang dalam melaksanakan tugas-tugas atau pekerjaannya sesuai dengan standar dan kriteria yang ditetapkan untuk pekerjaan itu. Dengan demikian, prestasi yang diperlihatkan sebagai seorang guru adalah aktivitas pembelajaran yang dapat diamati. Sedangkan tugastugas/pekerjaan yaitu sesuai dengan standar yang harus dilakukan guru meliputi persiapan, pelaksanaan, dan penilaian proses dan hasil belajar. Pekerjaan ini tidak bisa dilakukan oleh orang yang tidak memiliki keahlian sebagai guru. Ini berarti bahwa untuk menjadi seorang guru diperlukan syaratsyarat khusus, termasuk sebagai guru kimia.

Guru yang memiliki kinerja yang baik, seorang guru setidaktidaknya tiga kemampuan pokok yang harus dilakukan oleh guru, yaitu: (a) mampu merencanakan kegiatan belajar mengajar, (b) mampu mengelola kegiatan belajar mengajar, dan (c) mampu menilai kegiatan belajar mengajar (Robert M. Gagne, 1974:16-17). Ketiga faktor tersebut pada dasarnya merupakan bagian dari kompetensi guru. Sedangkan kemampuan mengajar guru, pada dasarnya merupakan pencerminan penguasaan guru atas kompetensinya (Ali Imron, 1995: 168). Ini berarti kompetensi merupakan seperangkat pengetahuan dan keterampilan yang harus dimiliki oleh seseorang dalam melaksanakan tugasnya. Dengan kata lain, kemampuan dan keterampilan mempunyai peran yang erat dengan kinerja dan merupakan suatu prasyarat bagi keberhasilan dalam suatu proses perwujudan kinerja (Utami Munandar, 1999: 17). Dengan keterampilan dan kemampuan seseorang guru dalam melakukan setiap aktivitas pembelajaran terutama dalam kelas dan disertai dengan latihan yang memadai, akan menghasilkan kinerja yang memuaskan, dan pada gilirannya 
akan melahirkan sumberdaya manusia yang berkualitas.

Tugas guru bukan hanya memberikan pengetahuan, melainkan mempersiapkan situasi yang menggiring anak untuk bertanya, mengamati, mengadakan eksperimen, serta menemukan fakta dan konsep sendiri (Conny Semiawan, 1997 :15). Dengan demikian, guru harus mampu mengelola dan memantau belajar siswa, menguasai teknik mengajar dan mempunyai sikap profesional yang diperoleh dari pengalaman, serta menjadi anggota profesi dan terlibat di dalamnya. Hal lain yang tidak kalah penting adalah kemampuan guru dalam pengelolaan kelas, yaitu kegiatan-kegiatan yang dapat menciptakan dan mempertahankan kondisi yang optimal agar pembelajaran dapat berlangsung efektif.

Istilah

"kecerdasan

emosional" dipopulerkan oleh

Daniel Goleman, seorang psikolog dan penulis buku Emotional Intelligence untuk menerangkan kualitas-kualitas emosional yang tampaknya penting bagi keberhasilan. Kualitas-kualitas keterampilan ini mencakup mengenali emosi diri, mengelola emosi, memotivasi diri sendiri, empati, dan membina hubungan dengan orang lain (Daniel Goleman, 1997: 57).

Pada dasarnya pengertian kecerdasan emosional tidak dapat lepas dari pengertian emosi. Emosi berasal dari kata latin movere, yang artinya "menggerakkan, bergerak", ditambah awalan "e" untuk memberi arti "bergerak menjauh", menyiratkan bahwa kecenderungan bertindak merupakan hal mutlak dalam emosi (Daniel Goleman, 1997 : 7). Goleman mendefinisikan emosi sebagai perasaan dan pikiran khas; suatu keadaan biologik dan psikologik; suatu rentang kecenderungankecenderungan untuk bertindak. Hal senada diungkapkan Mayer dalam Steinberg (1999) bahwa emosi merupakan sistem respon yang terkoordinir, emosi terjadi 
dalam keadaan biologis tertentu, keadaan eksperiensial tertentu, keadaan kognitif tertentu yang terjadi simultan; dan karena itu emosi menyatukan pikiran, perasaan dan tindakan (John M. Steinberg, 1999 : 1). Ini berarti bahwa emosi membebaskan dari kelumpuhan dan memotivasi kita untuk bertindak.

Salovey dan Mayer menggunakan istilah kecerdasan emosi untuk menggambarkan sejumlah keterampilan yang berhubungan dengan keakuratan penilaian tentang emosi diri sendiri dan orang lain, serta kemampuan mengelola perasaan untuk memotivasi, merencanakan, dan meraih tujuan kehidupan. Gardner dalam Pertiwi (1997) mendefinisikan kecerdasan emosional sebagai, kemampuan untuk memahami orang lain, apa yang memotivasi, serta cara bekerja dan cara bekerja sama dengan mereka. Kecerdasan emosional juga merupakan kemampuan untuk membedakan dan menanggapi dengan tepat suasana hati, temperamen, motivasi, dan hasrat orang lain (Aprilia Fajar Pertiwi,dkk 1997 :16). Pendapat lain menyatakan bahwa kecerdasan emosional adalah suatu keterampilan memahami diri sendiri, kemampuan mengatur diri sendiri, memotivasi dan empati, yang merupakan prediktor yang sangat kuat dan dapat dipercaya untuk meraih keberhasilan di tempat kerja. Karena itu, seseorang yang mempunyai kecerdasan emosional adalah seseorang yang menyadari emosinya sendiri dan emosi orang lain dan menyesuaikan perilakunya berdasarkan pengetahuannya tentang kecerdasan emosional tersebut (Vic Dulewicz and Malcolm Higgs, 2000 : 1). Dengan demikian seorang guru akan berhasil bila guru tersebut memiliki kecerdasan emosional yang tinggi, karena sangat diperlukan oleh guru. Hal ini didasarkan pada kenyataan bahwa guru sebagai panutan siswa dan masyarakat sekitarnya, disamping itu guru juga 
Sumiyati, Analisis Kinerja Guru Kimia SMA DKI Jakarta Ditinjau dari Kecerdasan Emosional

dihadapkan dengan siswa dari berbagai latar belakang yang berbeda.

Salah satu bagian otak yang ada hubungannya dengan kecerdasan emosional adalah Amigdala. Amigdala merupakan sel otak yang menghubungkan antara kecerdasan intelektual dengan kecerdasan emosional, yaitu antara kemampuan kognitif dengan kemampuan mengendalikan emosi sehingga orang menjadi sukses. Rasa sedih, marah, takut, nafsu dan lain-lain sangat tergantung pada amigdala. Jika amigdala dipisahkan dari bagian-bagian otak lainnya, hasilnya adalah ketidak mampuan yang amat mencolok dalam menangkap makna emosional suatu peristiwa. Kehilangan bobot emosional menyebabkan peristiwa-peristiwa tidak mempunyai makna. Orang yang amigdalanya terpotong tanpa sengaja dalam suatu operasi otak misalnya, akan sulit mengenal berbagai emosi dalam dirinya, apalagi mengekspresikannya, bahkan ia tidak mengenal lagi ibunya, dan tetap pasif meskipun menghadapi kecemasan. Amigdala berfungsi sebagai semacam gudang ingatan emosional, dan dengan demikian hidup tanpa amigdala merupakan kehidupan tanpa makna pribadi.

Terjadinya peristiwa di mana kekuatan emosi dapat mengalahkan rasio yakni karena amigdala mampu mengambil alih kendali tindakan, sewaktu otak masih menyusun keputusan (Joseph LeDoux, 1996 : 303). Kemungkinan terjadinya "pembajakan" emosi ini lebih besar pada orang yang memiliki kecerdasan emosi rendah, atau karena otak mereka dirakit dalam suasana tegang.

Dari uraian di atas, tampak bahwa manusia mempunyai dua kecerdasan yang berbeda, yaitu kecerdasan emosional dan kecerdasan Intelektual. Oleh Goleman diungkapkan bahwa setinggi-tingginya kecerdasan intelektual hanya menyumbang kira-kira $20 \%$ bagi faktor-faktor yang menentukan sukses dalam 
hidup, sisanya sebesar $80 \%$ diisi oleh kekuatan-kekuatan lain. Selanjutnya dikatakan bahwa "status akhir seorang dalam masyarakat pada umumnya ditentukan oleh faktor-faktor bukan kecerdasan intelektual saja, melainkan juga oleh kecerdasan emosional (Goleman, 1997 : 44). Hal ini sejalan dengan Shapiro (1997) menyatakan bahwa kecerdasan emosional bukanlah lawan kecerdasan intelektual, namun keduanya berinteraksi secara dinamis baik pada tingkatan konseptual maupun pada tingkat dunia nyata (Lawrence E. Shapiro, 1997: 9).

Dalam dunia pendidikan formal, kecerdasan intelektual kelihatannya lebih berperan dominan dari kecerdasan emosional. Suatu kecerdasan yang dibutuhkan untuk lebih dapat memahami dunia kognitif pengetahuan, penalaran dan abstraksi pembelajaran. Dunia kecerdasan emosional lebih dominan digunakan dalam dunia kerja dalam menghadapi kenyataan dan tantangan permasalahan yang kadangkala sangat menbutuhkan perasaan dan intuisi untuk tetap survive.

Selanjutnya Cooper dan Sawaf mengungkapkan kecerdasan emosional sebagai kemampuan kita untuk merasakan, memahami dan secara efektif dapat menerapkan daya dan kepekaan emosi sebagai sumber energi, informasi, koneksi dan menetapkan pengaruh terhadap orang lainnya (Robert K. Cooper and Ayman Sawaf, 1997 : xii xiii). Baron dalam Goleman (1997) mengungkapkan hal yang senada, bahwa kecerdasan emosional adalah serangkaian kemampuan, kompetensi, dan kecakapan non kognitif, yang mempengaruhi kemampuan seseorang untuk berhasil mengatasi tuntutan dan tekanan lingkungan. Sedangkan Solvey dan Mayer mendefinisikan kecerdasan emosional sebagai kemampuan untuk mengenali perasaan, meraih dan membangkitkan perasaan untuk membantu pikiran, memahami 
perasaan dan maknanya serta mengendalikan secara mendalam sehingga membantu perkembangan emosi dan intelektual. Dapat disimpulkan bahwa kecerdasan emosional adalah serangkaian kecakapan yang memungkinkan kita melapangkan jalan di dunia yang rumit, aspek pribadi, sosial, dan pertahanan dari seluruh kecerdasan, akal sehat yang penuh misteri dan kepekaan yang penting untuk berfungsi secara efektif setiap hari (Steven J. Stein dan Howard E, 2002 : 30-31).

$$
\text { Goleman (1997 : 57) }
$$

mengungkapkan 5 (lima) dimensi kecerdasan emosional, yaitu : kemampuan untuk: (a) mengenali emosi diri sendiri, (b) mengelola dan mengekspresikan emosi diri sendiri dengan tepat, (c) memotivasi diri sendiri, (d) mengenali emosi orang lain, dan (e) membina hubungan dengan orang lain. Kelima dimensi kecerdasan emosional tersebut akan diurai secara singkat dibawah ini.
Mengenali emosi diri, kesadaran diri untuk mengenali perasaan sewaktu perasaan itu terjadi merupakan dasar kecerdasan emosional. Kesadaran diri merupakan prasyarat bagi ke-empat dimensi lain. Ketidakmampuan untuk mencermati perasaan kita yang sesungguhnya membuat kita berada dalam kekuasaan perasaan. Orang yang memiliki keyakinan yang lebih tentang perasaannya adalah pilot yang andal bagi kehidupan mereka, karena mempunyai kepekaan lebih tinggi akan perasaan mereka yang sesungguhnya atas pengambilan keputusankeputusan sampai pada masalah pribadi. Kita tidak mungkin bisa mengendalikan sesuatu yang tidak kita kenal, jika kita tidak menyadari perbuatan kita. Tanpa kesadaran diri, meskipun kita telah bersungguh-sungguh berupaya untuk menyelesaikan permasalahan satu demi satu, kita tidak bisa memantau kemajuan yang telah diraih, dan kesempatan kita untuk mencapai 
sasaran akan sangat terkendala. Dengan adanya kesadaran diri maka seseorang dapat mengetahui keadaan mereka, dan dengan mengetahui keadaannya maka dapat mengubah perilaku mereka agar menjadi lebih baik.

Unsur kecerdasan

emosional ini mencakup seluruh kemampuan kita untuk menyesuaikan diri dengan lingkungan yang tidak biasa, tidak terduga, dan dinamis. Orang yang fleksibel adalah orang yang tangkas, mampu bekerja sama yang menghasilkan sinergi, dan dapat menanggapi perubahan secara luwes. Orang seperti ini bersedia berubah pikiran jika ada bukti yang menunjukkan bahwa mereka salah. Pada umumnya mereka terbukti dan mau menerima gagasan, orientasi, cara dan kebiasaan yang berbeda. Namun demikian, individu yang menyangkal emosi yang mendalam dapat menyebabkan diskoneksi (Cooper and Ayman Sawaf, 1997: 466) Diskoneksi ini dapat mengakibatkan

seseorang kehilangan sentuhan dengan aspek-aspek yang berkaitan dengan keberadaan dirinya. la cenderung menjadi orang yang mudah tersinggung, penakut, penyangkal, dan takut terhadap kritik.

Kecerdasan emosional merupakan suatu dimensi kemampuan manusia yang berupa keterampilan emosional dan sosial yang kemudian membentuk watak atau karakter dengan melibatkan kemampuankemampuan seperti kemampuan mengendalikan diri, empati, motivasi, kesabaran, ketekunan, dan keterampilan sosial, sehingga sukses dalam pekerjaaan dan membina hubungan dengan orang lain. Kecerdasan emosional memiliki lima dimensi, yaitu : mengenali emosi diri, yang berarti memilki pengetahuan akan emosi sendiri, (2) mengelola emosi, berarti terampil mengatur perasaan sendiri, (3) memotivasi diri sendiri, dapat memanfaatkan perasaan untuk tujuan tertentu, 
Sumiyati, Analisis Kinerja Guru Kimia SMA DKI Jakarta Ditinjau dari Kecerdasan Emosional

(4) mengenali emosi orang lain yang berarti dapat memahami perasaan orang dan merupakan sumber empati, dan (5) membina hubungan yang berarti dapat mengendalikan perasaan orang lain. Kelima dimensi tersebut merupakan modal utama yang dimiliki oleh setiap orang terutama bagi seorang guru yang karena pekerjaannya setiap hari harus berhadapan dengan siswa dari beragam latar belakang. Dengan demikian, agar dapat berhasil guna, para guru perlu mengembangkan atau meningkatkan kelima dimensi tersebut. Kinerja guru berkaitan dengan keberhasilannya dalam mengenali perasaan siswa (empati). Dengan kemampuan berempati yang dimiliki, guru dengan mudah menerapkan strategi atau metode yang paling tepat atau sesuai dengan keadaan siswa dalam proses belajar-mengajar.

Hal ini juga berdampak pada keberhasilan guru dalam mengelola hubungan dengan siswa atau antara siswa dan siswa, mengendalikan dan menjaga ketertiban kelas, mengelola kegiatan pembelajaran serta meningkatkan prestasi siswa. Untuk mencapai keberhasilan dalam mengelola berbagai kegiatan tersebut, dibutuhkan kemampuan mengelola emosi sendiri dan emosi orang lain, serta memanfaatkan emosi tersebut dalam bekerjasama dengan orang lain. Ini berarti bahwa untuk mencapai kinerja guru yang tinggi, dibutuhkan kecerdasan emosional yang tinggi pula. Penjelasan itu mengimplikasikan dugaan bahwa terdapat hubungan positif antara kecerdasan emosional dengan kinerja guru.

Berdasarkan kajian pustaka yang telah diuraikan di atas, maka dirumuskan hipotesis sebagai berikut :Terdapat hubungan positif antara kecerdasan emosional dan kinerja guru kimia. Artinya semakin tinggi kecerdasan emosional, akan semakin tinggi kinerja guru kimia 


\section{Metodologi Penelitian}

Penelitian ini dilaksanakan kepada guru-guru kimia SMA di DKI Jakarta dengan menggunakan metode survei dengan disain korelasional. Dengan cara simple random sampling, diperoleh sebanyak 118 guru kimia SMA Negeri di DKI Jakarta yang dijadikan responden. Variabel penelitian ini terdiri atas variabel bebas dan

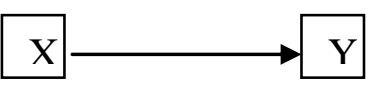

Gambar 1.

Keterangan:

$\mathrm{Y}=$ kinerja guru kimia

$\mathrm{X}=$ kecerdasan emosional

Penelitian ini menggunakan dua macam perangkat instrumen, yaitu (1) skala kinerja guru kimia, dan (2) skala kecerdasan emosional. Instrumen penelitian yang telah disusun berdasarkan konsep dan landasan teori, diujicobakan pada sejumlah responden. Dari hasil ujicoba diperoleh koefisien reliabilitas (1) instrumen kinerja guru kimia variabel terikat. Adapaun variabel bebasnya adalah kecerdasan emosional guru kimia di DKI Jakarta, dan variabel terikatnya adalah kinerja guru kimia di DKI Jakarta. Hubungan antara variabel-variabel bebas dan variabel terikat pada penelitian ini dapat digambarkan dalam bentuk konstelasi hubungan antara variabel seperti tampak pada gambar 1. sebesar 0,86; (2) instrumen kecerdasan emosional sebesar 0,91

4. Hasil Penelitian dan Pembahasan

Hasil penelitian kinerja guru kimia dengan variabel kecerdasan emosional dapat dilihat pada rangkuman deskripsi data pada Tabel 1 
Sumiyati, Analisis Kinerja Guru Kimia SMA DKI Jakarta Ditinjau dari Kecerdasan Emosional

\begin{tabular}{cccccccc}
\hline $\begin{array}{c}\text { Variab } \\
\text { el }\end{array}$ & $\begin{array}{c}\text { Skor } \\
\text { teoreti } \\
\text { s }\end{array}$ & $\begin{array}{c}\text { Skor } \\
\text { empiri } \\
\text { s }\end{array}$ & $\begin{array}{c}\text { Rentan } \\
\text { g Skor }\end{array}$ & $\begin{array}{c}\text { Rerat } \\
\text { a }\end{array}$ & $\begin{array}{c}\text { Simpang } \\
\text { an baku }\end{array}$ & $\begin{array}{c}\text { Modu } \\
\text { s }\end{array}$ & $\begin{array}{c}\text { Media } \\
\mathbf{n}\end{array}$ \\
\hline $\mathrm{Y}$ & $37-185$ & $\begin{array}{c}102- \\
157\end{array}$ & 55 & 130,1 & 9,74 & 129,6 & 129,8 \\
$\mathrm{X}$ & $47-235$ & $\begin{array}{c}155- \\
155\end{array}$ & 69 & 189,1 & 12,4 & 189,3 & 189,2 \\
& & 224 & & & & & \\
\hline
\end{tabular}

Pengujian persyaratan normalitas data menggunakan teknik uji Lilliefors dan pengujian persyaratan homogenitas varians populasi menggunakan teknik uji Bartlett. Rangkuman pengujian persyaratan analisis termuat dalam Tabel 2 dan Tabel 3.

Tabel 2: Rangkuman Hasil Uji Normalitas Galat Taksiran Regresi $\hat{Y}=a+$ $b X$

\begin{tabular}{|l|l|l|l|l|}
\hline $\begin{array}{l}\text { Galat Taksiran } \\
\text { Regresi }\end{array}$ & $L_{o}$ & $L_{t}(\alpha=0,01)$ & $\begin{array}{l}\text { Kesimpula } \\
n\end{array}$ & $\begin{array}{l}\text { Keteranga } \\
n\end{array}$ \\
\hline $\mathrm{Y}$ atas $\mathrm{X}$ & 0,0931 & 0,0949 & Terima $\mathrm{H}_{0}$ & Normal \\
\hline
\end{tabular}

Keterangan :

$$
\begin{aligned}
& Y=\text { kinerja guru klmia } \\
& X=\text { kecerdasan emosional } \\
& L_{o}=\text { harga } L \text { hitung; } \\
& L_{t}=\text { harga } L \text { tabel Lilliefors }
\end{aligned}
$$

Tabel 3. Rangkuman Hasil Uji Homogenitas

\begin{tabular}{|l|l|l|l|l|l|}
\hline Varians & Dk & $\chi^{2}{ }_{h}$ & $\chi^{2}(\alpha=0,01)$ & $\begin{array}{l}\text { Kesimpula } \\
n\end{array}$ & Keterangan \\
\hline $\mathrm{Y}$ atas $\mathrm{X}$ & 52 & 28,74 & 78,64 & Terima $\mathrm{H}_{0}$ & Homogen \\
\hline
\end{tabular}

Keterangan :

$\mathrm{Y}=$ Kinerja guru kimia

$\mathrm{dk}=$ Derajat kebebasan

$\mathrm{X}=$ Kecerdasan emosional

$\chi^{2} h=$ Harga chi-kuadrat hasil pengamatan

$\chi^{2}=$ Harga chi-kuadrat tabel Bartlett

Pengujian hipotesis penelitian ini menggunakan rumus regresi dan korelasi. Hipotesis diuji dengan teknik analisis regresi linear sederhana dan korelasi sederhana dan dilanjutkan dengan uji t. Perhitungan regresi sederhana kinerja guru kimia atas kecerdasan emosional diperoleh persamaan regresi $\hat{Y}=45,74+0,45 X$. Pengujian signifikansi koefisien regresi 
dan linearitas antara kecerdasan emosional $(X)$ dengan kinerja guru kimia (Y) dapat dilihat pada Tabel 5.

Tabel 4 Daftar ANAVA untuk Uji Signifikansi dan Linearitas

\begin{tabular}{|c|c|c|c|c|c|c|}
\hline Sumber & & & & & & \\
\hline Varians & $\mathbf{d k}$ & $\mathrm{JK}$ & RJK & $F_{h}$ & $\alpha=.05$ & $\alpha=.01$ \\
\hline Total & 118 & 2006858 & - & - & - & - \\
\hline Regresi (a) & 1 & 1995760, & 1995760 & & & \\
\hline Regresi (b/a) & 1 & 3 & 3 & $55,66^{\star *}$ & 33,93 & 6,86 \\
\hline Sisa & 116 & $\begin{array}{l}3598,6 \\
7499,1\end{array}$ & $\begin{array}{r}3598,7 \\
64,6\end{array}$ & & & \\
\hline $\begin{array}{l}\text { Tuna Cocok } \\
\text { Kekeliruan }\end{array}$ & $\begin{array}{l}51 \\
65\end{array}$ & $\begin{array}{c}3726,4 \\
3772,7\end{array}$ & $\begin{array}{c}73,1 \\
58,0\end{array}$ & $1,26^{\text {ns }}$ & 1,54 & 1,83 \\
\hline
\end{tabular}

Keterangan :

$\mathrm{dk}=$ derajat kebebasan

$\mathrm{F}_{\text {hitun }} \mathrm{F}=\mathrm{F}$ dari perhitungn

$\mathrm{Jk} \quad=$ Jumlah Kuadrat

$F_{\text {tabel }}=\mathrm{F}$ dari tabel

RJK = Rerata Jumlah Kuadrat

** $\quad=$ Regresi sangat signifikan $\left(F_{\text {hit }}=55,665>F_{11 \%}=6,862\right)$

ns $=$ non signifikan $=$ regresi linier, $\left(F_{\text {hit }}=1,259<F_{t 5 \%}=1,538\right)$

Analisis korelasi sederhana terhadap skor kecerdasan emosional $(X)$ dan skor kinerja guru kimia $(Y)$ menunjukkan koefisien korelasi $r_{\mathrm{y} 2}$ sebesar 0,57 . Hal tersebut ternyata signifikan pada $\alpha=0,01$, seperti terlihat pada Tabel 8. Dengan Koefisien determinasi $r_{y 2}^{2}=0,32$ mempunyai arti bahwa $32 \%$ variasi yang terjadi pada kinerja guru kimia dapat dijelaskan oleh variasi kecerdasan emosional melalui persamaan regresi : $\hat{Y}=45,74+0,45 X$.

Tabel 5. Uji Signifikansi Koefisien Korelasi $r_{y 2}$.

\begin{tabular}{|c|c|c|c|c|}
\hline Cacah Observasi & \multirow{2}{*}{ Koefisien Korelasi } & \multirow{2}{*}{$\mathbf{t}_{\text {hitung }}$} & \multicolumn{2}{|c|}{$\mathbf{t}_{\text {tabel }}$} \\
\cline { 4 - 5 } & & $\mathbf{\alpha = 0 , 0 5}$ & $\mathbf{\alpha}=\mathbf{0 , 0 1}$ \\
\hline 118 & $\mathrm{r}_{\mathrm{y} 2}=0,57$ &, $46^{* *}$ & 1,66 & 2,36 \\
\hline${ }^{* *}=$ koefisien korelasi sangat signifikan & \multicolumn{3}{|l}{}
\end{tabular}

Hasil pengujian hipotesis emosional mempunyai hubungan menunjukkan bahwa "kecerdasan positif dengan kinerja guru kimia", 
dengan koefisien korelasi akhirnya juga akan berdampak sederhana $r_{y 2}=0,57$, bentuk pada kinerja organisasi sekolah. hubungan dinyatakan dalam Dengan demikian, temuan ini persamaan regresi $\hat{Y}=45,74+\quad$ memberikan bukti empirik bahwa 0,45X. Koefisien determinasi makin tinggi kecerdasan sebesar 0,32 menunjukkan bahwa $32 \%$ variasi yang terjadi pada kinerja guru kimia dapat dijelaskan oleh variasi kecerdasan emosional. Hal ini berarti bahwa apabila seorang guru kimia mempunyai kecerdasan emosional yang tinggi, akan memperoleh kinerja yang baik dan memuaskan.

Temuan di atas, ternyata terdapat keterkaitan yang cukup kuat antara kecerdasan emosional dan kinerja guru kimia. Temuan ini sesuai dengan Wibowo (1996: 6) bahwa kecerdasan emosional merupakan salah satu indikator kebermutuan kepala sekolah dan guru. Temuan penelitian ini juga diperkuat oleh hasil penelitian Ratna Kesuma (2001:185) yang menyatakan bahwa kecerdasan emosional berpengaruh pada kinerja kepala sekolah yang pada emosional akan makin tinggi pula kinerja guru kimia.

\section{Simpulan, Implikasi dan Saran}

Berdasarkan hasil pengolahan data serta pengujian hipotesis, dapat disimpulkan bahwa terdapat hubungan positif antara kecerdasan emosional dengan kinerja guru kimia SMA di DKI Jakarta. Hal ini berarti bahwa semakin tinggi kecerdasan emosional, maka akan semakin tinggi pula kinerja guru kimia dan sebaliknya. Hal ini berimplikasi kepada upaya peningkatan kecerdasan emosional melalui diciptakannya keharmonisan di tempat kerja dengan memperhatikan kesulitan yang dihadapi oleh setiap individu yang disebabkan oleh tugas di sekolah maupun di luar sekolah. Selain itu juga perlu memacu motivasi guru 
sebagai salah satu indikator kecerdasan emosional.

Berdasarkan kesimpulan dan implikasi hasil penelitian, maka berikut ini diajukan beberapa saran: a) Agar pembelajaran dapat terlaksana dalam kondisi yang menyenangkan dan kondusif bagi seluruh siswa untuk meraih hasil belajar yang tinggi, maka para guru kimia hendaknya senantiasa meningkatkan kinerjanya melalui peningkatan kecerdasan emosional; b) Guru kimia diharapkan mau belajar secara berkesinambungan untuk memperdalam dan memperluas pemahaman materi kimia dalam rangka mererapkan prinsip belajar sepanjang hayat; c) Kepada para pengambil kebijakan di bidang pendidikan, agar melakukan kegiatankegiatan sebagai berikut, (1) pembinaan kepala sekolah secara rutin agar dapat tercipta atau berlangsung komunikasi yang kreatif; (2) menciptakan situasi yang memungkinkan terjadinya interaksi, yang mengandung arti bagi pembinaan guru, (3) untuk mengikutsertakan guru-guru kimia dalam kegiatan seminar, lokakarya, penataran, pelatihan, dan melanjutkan pendidikan kejenjang yang lebih tinggi; d) Perlu dilakukan penelitian lebih lanjut, yang merupakan pendalaman, penyempurnaan atau perluasan studi ini dan apabila dimungkinkan, dapat melibatkan banyak faktor yang mampu dijadikan sebagai prediktor kinerja guru kimia.

\section{Acuan Pustaka}

Adiningsih, Nani Utami. 2004, Kualitas dan Profesionalisme Guru. file://A:/ Kualitas dan Profesionalisme Guru. htm.

As'ad, Muhamad, 1995, Psikologi Industri, Yogyakarta: Liberty.

Cooper, Robert $\mathrm{K}$ and Ayman Sawaf, 1997,. Executive $E Q$ Emotional Intelligence in Business. London: Orion Business Books.

Depdiknas. 1999, Laporan Hasil Uji Kompetensi Guru SMU. Jakarta: Kanwil Depdiknas DKI Jakarta. 
Sumiyati, Analisis Kinerja Guru Kimia SMA DKI Jakarta Ditinjau dari Kecerdasan Emosional

$\begin{array}{cr}\text { Departemen Pendidikan } & \text { dan } \\ \text { Kebudayaan. } & 1995, \\ \text { Kurikulum rekolah } & \text { Sekonah } \\ \text { Menengah } & \text { Umum } \\ \text { 1995: GBPP } & \text { Mata } \\ \text { Pelajaran } & \text { Kimia. } \\ \text { Jakarta. } & \end{array}$

Dick, Walter and Lou Carey. 1985, The Systematic Design of Instruction. London: Scott Foresman and Company.

Dulewicz, Vic and Higgs, Malcolm. 2000, Emotional Intelligence You Can't Afford to Ignore It, ASE (http://www. asesolutions.co.ak/ei/Defa ult.htm,.

Gagne, Robert M. 1974, Essensials of Learning for Instruction. New York: Holt, Rinehart and Winston.

Goleman, Daniel. 1997, Emotional Intelligence (Kecerdasan Emosional), terjemahan T.Hermaya. Jakarta: PT. Gramedia Pustaka Utama.

Imron, Ali, 1995, Pembinaan Guru Di Indonesia, Jakarta, PT Dunia Pustaka Jaya.

Kesuma, Ratna. 2001 "Pengaruh Pengetahuan tentang Pembelajaran,
Pengetahuan

Administrasi,

Kecerdasan

Emosional, Gaya

Kepemimpinan dan

Kreativitas terhadap

Kinerja Kepala

Sekolah", Disertasi.

Jakarta: PPs UNJ

Jakarta.

LeDoux, Joseph. 1996, The Emotional Brain: The Mysterious

Underpinnings of Emotional Life. New York: Simon \& Schuster.

Munandar, S.C. Utami, 1999, Kreativitas Dan Keberbakatan, Strategi mewujudkan Potensi Kreatif dan Bakat, Jakarta: Gramedia.

Pertiwi, Aprilia Fajar dkk., 1997 Mengembangkan

Kecerdasan Emosi

Anak. Jakarta:

Yayasan Aspirasi

Pemuda.

Semiawan,Conny. $\quad 1997$ Perspektif Pendidikan Anak Berbakat. Jakarta: PT. Gramedia Widiasarana Indonesia.

Shapiro, Lawrence E. , 1997, Mengajarkan

Emosional Intelligence pada Anak, diterjemahkan oleh: Alex Tri Kantjono. 
Jakarta: PT. Gramedia Pustaka Utama.

Stein, J. Steven dan E Howard, 2002, Ledakan EQ , terjemahan Trinanda Rainy Januar Sari dan Yudhi Murtanto, Bandung Kaifa.

Steinberg, John M. , 1999, What Are Emotions? EQ Today

(http://www.eqtoday.co m/ emotions.html.

Subiyanto. Kajian-Jurnal IImiah Triwulan Pendidikan da Kebudayaan. Jakarta: Balitbang Dikbud, Maret 1998
Suprastowo, Philip., 2001, Guru Pada Era Reformasi: Kajian dalam Meningkatkan Profesionalisme Guru. Jakarta: Pusat Penelitian Kebijakan Balitbang Depdiknas

Whitmore, John, 1997, Coaching For Performance, Seni Mengarahkan Untuk Mendongkrak Kinerja. Jakarta: Gramedia.

Wibowo, Mungin Eddy. , 1996, Peran Guru dalam Reformasi Sekolah, Suara Merdeka. Jakarta: Suara Merdeka. 